University of St. Thomas, Minnesota

UST Research Online

2011

Cash Conversion Cycle Management in Small Firms Relationships with Liquidity, Invested Capital, and Firm Performance

Jay J. Ebben

University of St.Thomas, Minnesota, jjebben@stthomas.edu

Alex C. Johnson

University of St. Thomas, Minnesota, acjohnson2@stthomas.edu

Follow this and additional works at: https://ir.stthomas.edu/ocbentrpub

Part of the Entrepreneurial and Small Business Operations Commons

This Article is brought to you for free and open access by the Entrepreneurship at UST Research Online. It has been accepted for inclusion in Entrepreneurship Faculty Publications by an authorized administrator of UST Research Online. For more information, please contact asle4660@stthomas.edu. 


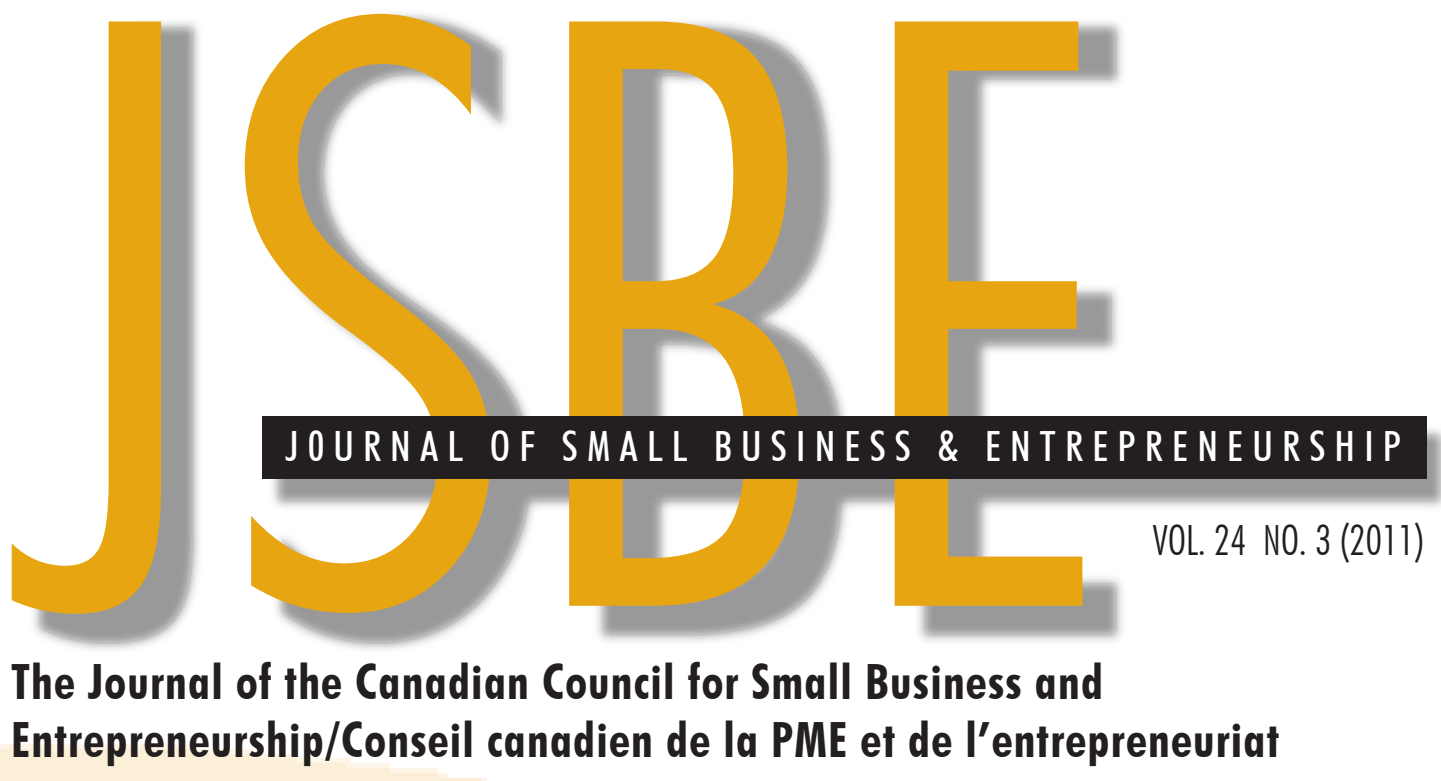

\section{INSIDE}

301 Business Environment and New Firm Creation: An International Comparison

Andrew Dyck and Tomi Ovaska

319 Contrasting Contexts for Entrepreneurship: Capitalism by Kyrgyz Decree Compared to Gradual Transition in Uzbekistan Frank Lasch and Léo-Paul Dana

329 Les déterminants de la communication financière sur Internet: Le cas des marchés non réglementés de Bruxelles Laetitia Pozniak and Mélanie Croquet

345 Autonomy, Locus of Control, and Entrepreneurial Orientation of Lebanese Expatriates Worldwide Philip W. Zgheib and Abdulrahim K. Kowatly

361 Acquisition of Institutional Capital by Niche Agricultural Producers Jing Zhang and Howard Van Auken

381 Cash Conversion Cycle Management in Small Firms: Relationships with Liquidity, Invested Capital, and Firm Performance Jay J. Ebben and Alec C. Johnson

397 Entrepreneurial Orientations of Women Business Founders from a Push/Pull Perspective: Canadians versus non-CanadiansA Multinational Assessment Dafna Kariv

427 Microfinance Institutions: A Cross-Country Empirical Investigation of Outreach and Sustainability Ashim Kumar Kar 


\title{
Cash Conversion Cycle Management in Small Firms: Relationships with Liquidity, Invested Capital, and Firm Performance
}

\author{
Jay J. Ebben, Schulze School of Entrepreneurship, University of St. Thomas
}

Alec C. Johnson, Schulze School of Entrepreneurship, University of St. Thomas

\begin{abstract}
This study investigated the relationship between cash conversion cycle and levels of liquidity, invested capital, and performance in small firms over time. In a sample of 879 small U.S. manufacturing firms and 833 small U.S. retail firms, cash conversion cycle was found to be significantly related to all three of these aspects. Firms with more efficient cash conversion cycles were more liquid, required less debt and equity financing, and had higher returns. The results also indicate that small firm owners/managers may be reactive in managing cash conversion cycle. The study highlights the importance of cash conversion cycle as a proactive management tool for small firm owners.
\end{abstract}

RÉSUMÉ. Cette étude examine le lien entre le cycle d'exploitation et les niveaux de liquidité, le capital investi, et le rendement chez les petites entreprises au fil du temps. Les résultats obtenus à partir d'un échantillon de 879 petites entreprises manufacturières américaines et 833 petites entreprises américaines de vente au détail révèlent que le cycle d'exploitation est lié de façon significative à ces trois aspects. Les entreprises avec des cycles d'exploitation plus courts avaient plus de liquidités, nécessitaient moins de financement par emprunt et par actions, et avaient des rendements supérieurs. Les résultats révèlent également que les propriétaires/gestionnaires de petites entreprises ont peut-être une approche réactive à la gestion du cycle d'exploitation. L'étude souligne l'importance du cycle d'exploitation comme outil de gestion proactive pour les propriétaires de petites entreprises.

\section{Introduction}

It has been well documented that small firms face significant constraints in raising outside debt and equity capital. Lenders and investors are reluctant to provide financing to small firms due to risks and costs involved, making outside financing difficult and expensive for these firms to obtain (e.g. Cassar, 2004; Levenson and Willard, 2000; Rajan and Zingales, 1995; Berger and Udell, 1995; Holtz-Eakin, Joulfaian, and Rosen, 1994). Additionally, obtaining outside capital is often undesirable for small business owners for personal reasons relating to control, debt aversion, and unfamiliarity with the fund-raising process (Cassar, 2004). These financial constraints, combined with liability of smallness, inexperienced management, and other factors lead to high failure rates among small firms (Forbes and Milliken, 1999; Pissarides, 1999; Cooper, Gimeno-Gascon, and Woo, 1994; Chandler and Hanks, 1994; Stinchcombe, 1965).

Because of these capital constraints, it is critical that small firms manage cash effectively through efficient handling of working capital. Cash flow management is touted as the "one thing that will make or break a small business" (Opiela, 2006: 26), as "more important, more misunderstood, and more often overlooked" than other financial disciplines (Fraser, 1998: 124), and as being "crucial for the survival and growth of small firms" (Pa- 
dachi, 2006: 46). The availability of cash dictates whether the firm can pay employees, suppliers, banks, landlords, and even the owner's salary; in short, small business management is cash flow management. However, it is widely recognized that small firms face serious difficulties when it comes to managing cash and working capital (Dodge, Fullerton, and Robbins, 1994), and that ineffective management of working capital is prevalent in small firms (Dunn and Cheatham, 1993; Berryman, 1983; Smith, 1973).

In recent years, the cash conversion cycle has become an increasingly popular tool for analyzing a firm's cash management. Cash conversion cycle is the "net time interval between actual cash expenditures on a firm's purchase of productive resources and the ultimate recovery of cash receipts from product sales" (Richards and Laughlin, 1980: 34); in effect, it measures a firm's days of inventory and receivables versus its days of payables. Noting this popularity, researchers have begun focusing more attention on cash conversion cycle as a predictor of firm outcomes. Studies on this relationship have consistently found that more efficient cash conversion cycles lead to higher returns in both large firms (Lazaridis and Tryfonidis, 2006; Deloof, 2003; Wang, 2002; Shin and Soenen, 1998; Jose, Lancaster, and Stevens, 1996) and small firms (Garcia-Teurel and Martinez-Solano, 2007; Padachi, 2006). These findings lend credence to cash conversion cycle as an important management tool that warrants further investigation, especially at the small firm level.

The study outlined in this paper contributes to the literature on cash management in small firms in three ways: 1) by analyzing how cash conversion cycle impacts not only firm returns but also liquidity and capital requirements; 2) by analyzing how firm performance and liquidity levels in turn influence cash conversion cycle; and 3) by analyzing how the relationships between cash conversion cycle and firm performance, liquidity and capital requirements change over time. The results of this study of 879 small U.S. manufacturing firms and 833 small U.S. retail firms indicate that more efficient cash conversion cycles increase small firm performance and liquidity while reducing capital requirements, and that small firm owners are reactionary when it comes to managing their cash conversion cycles. These results suggest that emphasis should be placed on educating small firm owners about the importance of working capital management, as proactive attention to working capital may help small firms to avoid periods of financial distress.

The remainder of this paper begins with a review of the literature on cash management and small firm finance. This is followed by the development of hypotheses around the relationships between cash conversion cycle and capital requirements, liquidity, and returns, and how this may change over time. Next, the sample, data description, and methods for analysis are discussed along with the results of the analysis. Finally, conclusions are drawn based on the results and limitations of the study and suggestions for future research are proposed.

\section{Literature Review and Hypotheses}

\section{Cash Management and Small Firm Finance}

Much of the research on small firm finance has demonstrated that these firms are generally undercapitalized and limited in the amounts of outside debt and equity capital that is available to finance operations and growth (e.g. Berger and Udell, 1995; Rajan and Zingales, 1995; Storey, 1994; Stiglitz and Weiss, 1981). These financial constraints are generally due to information asymmetries and transaction costs that small firms face (Cassar, 2004; Watson and Wilson, 2002). Information asymmetries are higher in small firms due to lack of 
available public information (Carpenter and Petersen, 2002), which leads sources of financing to view small firms as risky investments and to only offer limited amounts of financing at a higher price (Shane and Cable, 2002). In terms of transaction costs, it is more costly in relative terms for providers of financing to make small loans or investments and this cost is passed on to the business (Egeln, Licht and Steil, 1997; Stiglitz and Weiss, 1981). Empirical evidence supports this notion, with studies finding that smaller and younger firms more often encounter liquidity constraints from lack of outside financing (Egeln, Licht and Steil, 1997) and that smaller and younger firms are less likely to receive bank financing (Levenson and Willard, 2000).

In addition, small firm owners often do not desire outside financing because of the control requirements that banks and investors demand, because they are inexperienced in raising capital, and because they are risk averse when it comes to taking on debt (Cassar, 2004; Bhide, 1992). The pecking order model of finance, which expects that it is more desirable for firms to look to internal methods of finance before seeking outside debt and equity (Myers, 1984), has been found to be "particularly strong in relation to the closely-held firms where information asymmetries [...] would be most apparent" (Watson and Wilson, 2002: 576). Others have also found that small firms are likely to follow the pecking order even during periods of growth (e.g. Carpenter and Petersen, 2002; Norton, 1991). Given these capital constraints, cash flow management is of primary importance in small firms, as effective cash management may reduce or even eliminate the need for outside capital.

\section{Cash Conversion Cycle and Invested Capital}

Though widely used to evaluate the health of firms, traditional measures of liquidity such as the current ratio reveal little about a firm's management of working capital (Johnson, Pricer, and Nenide, 2004; Eljelly, 2004). In fact, the use of these measures encourages managers to maintain higher levels of receivables and inventory relative to payables, and these assets must be financed by expensive debt and equity capital (Brophy and Shulman, 1992). Firms that more efficiently manage their working capital (and maintain lower current ratios) can finance a greater portion of their operations via payables and reduce the amount of outside capital required (Richards and Laughlin, 1980).

The limitations of these traditional liquidity measures have led to the rising popularity of the cash conversion cycle or cash gap as a means for analyzing working capital management (Richards and Laughlin, 1980). This approach measures the amount of time that elapses between when a firm pays for productive assets like inventory and when cash is collected after sales are generated on those assets. The equation for cash conversion cycle is the age of inventory (inventory divided by cost of goods sold per day) plus the receivables collection period (accounts receivable divided by sales per day) less the payment deferral period (non-interest-bearing current liabilities divided by cash expense per day). Achieving higher turnover of inventory and receivables while extending the time period taken to pay non-interest-bearing current liabilities should allow a firm to operate with lower levels of outside debt and equity capital. In fact, Winborg and Landstrom (2001) and Ebben and Johnson (2006) found in studies of bootstrapping that speeding up collections and delaying payments to suppliers were identified by small firm owners as important methods for reducing the need for outside debt and equity financing.

H1: Small firms with shorter cash conversion cycles will require lower levels of invested capital. 


\section{Effects on Small Firm Performance and Liquidity}

The relationship between cash conversion cycle and firm performance has been extensively analyzed in large firms, and these studies have generally revealed that an inverse relationship exists. For example, Shin and Soenen (1998) found a negative relationship between cash conversion cycle and market measures of stock returns and operating profits in a sample of large American corporations over a 20-year period. Similar results have been found in Belgian corporations (Deloof; 2003), in firms in the Athens Stock Exchange (Lazaridis and Tryfonidis, 2006), in a sample of Compustat firms (Jose, Lancaster, and Stevens, 1996), and in a sample of Japanese and Taiwanese corporations (Wang, 2002). This evidence supports the view that effective working capital management increases returns by reducing cost of capital and by allowing firms to achieve higher levels of asset turnover.

It is expected that this relationship also exists in small firms. Not only do higher levels of receivables and inventory potentially require higher levels of costly capital, longer receivables cycles also increase the risk of uncollectable accounts, and higher levels of inventory also increase storage and inventory management costs and increase the risk of inventory obsolescence. It also could be argued that effective working capital management is indicative of overall firm management; better-managed firms might be expected to achieve higher financial performance.

Evidence from two recent studies on working capital management and performance in small firms supports this notion. In a sample of small Spanish firms, Garcia-Teurel and Martinez-Solano (2007) found that reducing days of inventory and days of receivables (and therefore shorter cash conversion cycles) had a positive impact on return on assets. Padachi (2006) found very similar evidence in a sample of small Mauritian manufacturing firms, with high investment in inventory and receivables and longer cash conversion cycles associated with lower return on assets.

H2: Small firms with shorter cash conversion cycles will have higher firm financial performance than other small firms.

Similarly, an inverse relationship is expected between cash conversion cycle and cash liquidity in small firms. Following the logic of Fazarri and Petersen (1993), firms are likely to maintain a relatively constant level of fixed assets because of the costs associated with both investing and divesting these assets. Given the limitations and undesirability surrounding outside debt and equity capital, small firms have a limited pool of capital with which to operate, so the variability in cash liquidity should be tied to investments in working capital. Firms that have longer cash conversion cycles will have larger working capital investments and will therefore be more cash constrained.

H3: Small firms with shorter cash conversion cycles will be more liquid than other small firms.

\section{Changes in Cash Conversion Cycle Over Time}

George (2005) found that over time, working capital resource requirements (measured by higher levels of receivables and inventory relative to payables) had a positive relationship with firm financial performance and concluded that high resource requirements force small firms to be efficient. However, it is possible that a different phenomenon is happening: small firms that perform well pay less attention to their working capital and allow receivables and inventory to grow, while underperforming firms are forced to create efficiencies in working capital (Fazarri and Petersen, 1993). Small firm owners and managers are generally less so- 
phisticated and experienced than their counterparts in large firms (Timmons, 1999), often times sales-driven or product/service-focused rather than administrative (Filley and Aldag, 1978), and generally spend less time planning and implementing systems and processes like those for handling receivables and payables (Busenitz and Barney, 1997). Because of this, many small firm owners become "fire fighters," only paying attention to certain internal management issues when they become problems. Some limited evidence exists in the literature on working capital management to support this notion, with Howorth and Westhead (2003) finding that more profitable small firms were less likely to take up working capital management routines. Therefore, it is hypothesized that small firms tend to facilitate cash flow through working capital when they are financially constrained, rather than using these techniques proactively as part of overall firm management.

H4a: Small firms that are experiencing lower financial performance are more likely than other small firms to decrease their cash conversion cycles over time.

H4b: Small firms that are experiencing liquidity constraints are more likely than other small firms to decrease their cash conversion cycles over time.

Since it is hypothesized that cash conversion cycle is negatively related to invested capital, firm financial performance, and liquidity, it is expected that firms that improve their cash conversion cycle over time will reduce invested capital, improve financial performance, and increase liquidity more than other firms.

H5a: Improving cash conversion cycle reduces the need for invested capital over time.

H5b: Improving cash conversion cycle has a positive impact on firm performance over time.

H5c: Improving cash conversion cycle has a positive impact on firm liquidity over time.

\section{Methods}

\section{Sample}

A sample of manufacturing firms and a sample of retail firms were selected from the Kauffman Financial and Business Research Database, which contains income statement and balance sheet information on privately held firms in the United States. This longitudinal database has been assembled from survey data over a period of years by the Ewing Marion Kauffman Foundation. Firms were selected that had financial data available from 2002, 2003, and 2004 (the most recent three years in the data set), manufacturing and retail SIC codes, and less than \$20 million in revenues, which is consistent with other researchers' definitions of small firms (Daily and Dalton, 1993; d'Ambroise and Muldowney, 1988). There were a total of 879 manufacturing firms and 833 retail firms in the database that fit these criteria.

\section{Independent and Dependent Variables}

Cash Conversion Cycle was calculated as the number of days of receivables plus the number of days of inventory less the number of days of payables for each firm (see Tables 1a and $1 \mathrm{~b}$ for statistics on all variables).

Invested Capital was measured as the total interest-bearing debt (notes payable plus current portion of long-term debt plus non-current portion of long-term debt) plus owners' equity. 


\begin{tabular}{|c|c|c|c|c|c|c|c|c|c|}
\hline Variable & $\mathrm{N}$ & Mean & s.d. & 1 & 2 & 3 & 4 & 5 & 6 \\
\hline 1. $\mathrm{CCC}$ & 841 & 54.18 & 58.29 & & & & & & \\
\hline 2. Inv. Cap. & 877 & $1,976,631$ & $2,226,086$ & $.202 * *$ & & & & & \\
\hline 3. NBP & 874 & $-113,390$ & $1,069,682$ & -.017 & .028 & & & & \\
\hline 4. Asset TO & 879 & 2.39 & 1.03 & $-.325 * *$ & $-.440 * *$ & -.049 & & & \\
\hline 5. ROIC & 855 & 7.82 & 15.50 & -.053 & -.013 & .046 & $.095^{* *}$ & & \\
\hline 6. CCC Chg. & 799 & 1.44 & 36.45 & $-.289 * *$ & -.037 & $.090 *$ & .051 & $.096^{* *}$ & \\
\hline 7. Log Sales & 879 & 6.56 & 0.39 & -.058 & $.658^{* *}$ & $-.194 * *$ & -.010 & $.082 *$ & .019 \\
\hline \multicolumn{10}{|l|}{$\begin{array}{l}+\mathrm{p}<.10 \\
* \mathrm{p}<.05 \\
* * \mathrm{p}<.01\end{array}$} \\
\hline
\end{tabular}

\begin{tabular}{|c|c|c|c|c|c|c|c|c|c|}
\hline Variable & $\mathrm{N}$ & Mean & s.d. & 1 & 2 & 3 & 4 & 5 & 6 \\
\hline 1. $\mathrm{CCC}$ & 782 & 112.65 & 95.18 & & & & & & \\
\hline 2. Inv. Cap. & 833 & $1,023,500$ & $1,035,040$ & .009 & & & & & \\
\hline 3. NBP & 833 & $-16,277$ & 323,397 & .014 & .048 & & & & \\
\hline 4. Asset TO & 833 & 2.57 & 1.28 & $-.621 * *$ & $-.243^{* *}$ & $-.130 * *$ & & & \\
\hline 5. ROIC & 833 & 3.48 & 8.43 & $-.119 * *$ & $.077 *$ & $.071^{*}$ & .049 & & \\
\hline 6. CCC Chg. & 774 & -0.01 & 42.83 & $-.212 * *$ & .057 & $.072 *$ & .013 & .070 & \\
\hline 7. Log Sales & 833 & 14.54 & 1.12 & $-.404 * *$ & $.691 * *$ & $-.193^{* *}$ & $-.304^{* *}$ & $.139^{* *}$ & .062 \\
\hline \multicolumn{10}{|l|}{$\begin{array}{l}+\mathrm{p}<.10 \\
* \mathrm{p}<.05 \\
* * \mathrm{p}<.01\end{array}$} \\
\hline
\end{tabular}

Liquidity was measured as the Net balance position. Unlike more traditional measures of liquidity, such as the quick or current ratios, net balance position is an estimate of the cash excess or shortage a firm has after financing its fixed asset and working capital needs. Net balance position is calculated as Working Capital Available less Working Capital Required; Working Capital Available is equal to non-current-interest-bearing debt plus owners' equity less net fixed assets, and Working Capital Available is equal to a minimum cash cushion plus accounts receivable plus inventory less accounts payable. For this study, five days of sales was used as the minimum cash balance, consistent with Johnson, Pricer, and Nenide (2004). Net balance position was selected as the measure of liquidity because it has been demonstrated to more effectively estimate a firm's ability to meet its short-term cash expenditure obligations than more traditional measures (Johnson, Pricer, and Nenide, 2004).

Firm Performance was measured via two common measures of performance: asset turnover and return on invested capital. Asset turnover was calculated as sales divided by total assets and return on invested capital was calculated as net income divided by the sum of interest-bearing debt and owners' equity. 
Change in Cash Conversion Cycle was measured as the change in number of days between 2002 and 2003.

\section{Control Variables}

Industry and Firm Size were used as control variables in the regression analysis. Industry was controlled using a dummy variable for each two-digit SIC code. Firm size was measured as the log of 2002 net sales. Log sales was used as a means of obtaining a normal distribution.

\section{Data Adjustments}

The independent and dependent variables were winsorized at the 5th and 95th percentiles to reduce the impact of outliers. This technique has been recommended as an effective method for addressing outliers and obtaining normal distributions without the loss of data (Kennedy, Lakonishok, and Shaw, 1992). Firms with negative equity were excluded from analyses that included return on invested capital, as negative equity could provide misleading results. In the sample of manufacturing firms, 25 firms in the sample had negative equity in 2002, 31 firms had negative equity in 2003, and 36 firms had negative equity in 2004. In the sample of retail firms, 21 firms in the sample had negative equity in 2002, 19 firms had negative equity in 2003, and 23 firms had negative equity in 2004.

\section{Analysis and Results}

To test hypotheses 1, 2, and 3 (impact of cash conversion cycle on invested capital, firm performance, and liquidity), stepwise regression models were analyzed that included firm size and industry as the control variables, cash conversion cycle as the independent variable, and invested capital, asset turnover, return on invested capital, and liquidity as the dependent variables (see Tables $2 \mathrm{a}$ and $2 \mathrm{~b}$ ). The results for both the manufacturing and retail samples provide support for these hypotheses, with cash conversion cycle having a positive and significant effect on levels of invested capital and a negative and significant effect on asset turnover, return on invested capital, and net balance position.

To test Hypotheses $4 \mathrm{a}$ and $4 \mathrm{~b}$ (impact of firm performance and liquidity on change in cash conversion cycle), stepwise regression models were analyzed that included firm size and industry as the control variables, asset turnover, return on invested capital, and net balance position as the independent variables, and change in cash conversion cycle as the dependent variable. Support was also found for these hypotheses, with all three independent variables having a positive and significant impact on change in cash conversion cycle in the manufacturing firm sample, and with return on invested capital and net balance position having a positive and significant impact on change in cash conversion cycle in the retail firm sample (see Tables $3 a$ and $3 b$ ). For more in-depth analysis, this same regression was run with the change in age of inventory from 2002-2003, change in collection period from 2002-2003, and change in payment deferral period from 2002-2003 as dependent variables. In the sample of manufacturing firms, asset turnover and return on invested capital had a significant positive impact on change in age of inventory, and net balance position had a significant positive impact on change in collection period. In the sample of retail firms, net balance position had a significant positive impact on change in collection period, while return on invested capital had a significant negative impact on change in payment deferral period.

To test Hypotheses 5a, 5b, and 5c (impact of change in cash conversion cycle on invested capital, firm performance, and liquidity), stepwise regression models were analyzed 
that included firm size, industry, 2002 invested capital, 2002 asset turnover, 2002 return on invested capital, and 2002 net balance position as control variables, change in cash conversion cycle as the independent variable, and 2003 and 2004 measures of invested capital, asset turnover, return on invested capital, and net balance position as the dependent variables. Again, some evidence of support was found for these hypotheses, with change

\begin{tabular}{|c|c|c|c|c|}
\hline \multirow[b]{2}{*}{ Ind. Variables } & \multicolumn{4}{|c|}{ Dependent Variables } \\
\hline & $\begin{array}{c}\text { Model 1: } \\
\text { Invested Capital }^{\mathrm{b}}\end{array}$ & $\begin{array}{c}\text { Model 2: } \\
\text { Asset Turnover }\end{array}$ & $\begin{array}{c}\text { Model 3: } \\
\text { Return on Inv. Capital }\end{array}$ & $\begin{array}{c}\text { Model 4: } \\
\text { Net Balance Position }\end{array}$ \\
\hline Intercept & $-20.0^{* *}(.962)$ & $4.175^{* *}(.596)$ & $-7.923(9.892)$ & $2.477 * *(.748)$ \\
\hline Log Sales & $3.96^{* *}(.140)$ & $-.221 * *(.087)$ & $3.040 *(1.446)$ & $.398^{* *}(.114)$ \\
\hline $\mathrm{SIC}^{\mathrm{c}}$ & - & - & - & - \\
\hline $\mathrm{CCC}$ & $.0095 * *(.0009)$ & $-.006^{* *}(.001)$ & $-.018 *(.010)$ & $-.0011+(.0008)$ \\
\hline $\mathrm{F}$ & $47.460 * *$ & $9.532 * *$ & $1.315+$ & $1.396+$ \\
\hline $\mathrm{R}^{2}$ & .537 & .189 & .032 & .033 \\
\hline Adj. $R^{2}$ & .526 & .169 & .008 & .009 \\
\hline \multicolumn{5}{|c|}{$\begin{array}{l}{ }^{a} \text { Standard errors are in parentheses } \\
\text { b In millions } \\
{ }^{\mathrm{c}} \text { SIC } 25 \text { significant at } .05 \text { level for Model 1; SIC 22, 23, 25, 27, 32, 35, and } 36 \text { significant at .05 for Model 2; SIC 24, 26, 30, } \\
\text { and } 32 \text { significant at } .05 \text { for Model 3; SIC } 23 \text { significant at } .05 \text { level for Model } 4 \\
+p<.10 \\
\begin{array}{ll}* & p<.05 \\
* * & p<.01\end{array}\end{array}$} \\
\hline
\end{tabular}

Table 2b. Stepwise Regression Results for Hypotheses 1, 2 and 3 a (Retail Firms)

\begin{tabular}{|c|c|c|c|c|}
\hline \multirow[b]{2}{*}{ Ind. Variables } & \multicolumn{4}{|c|}{ Dependent Variables } \\
\hline & $\begin{array}{c}\text { Model 1: } \\
\text { Invested Capital }^{\mathrm{b}}\end{array}$ & $\begin{array}{c}\text { Model 2: } \\
\text { Asset Turnover }\end{array}$ & $\begin{array}{c}\text { Model 3: } \\
\text { Return on Inv. } \\
\text { Capital }\end{array}$ & $\begin{array}{c}\text { Model 4: } \\
\text { Net Balance Position }\end{array}$ \\
\hline Intercept & $-10.6^{* *}(.383)$ & $2.343 * *(.552)$ & $-6.800(4.701)$ & $.916 * *(.179)$ \\
\hline Log Sales & $.770 * *(.025)$ & $.081 * *(.036)$ & $.803 *(.310)$ & $-.061 * *(.012)$ \\
\hline $\mathrm{SIC}^{\mathrm{c}}$ & - & - & - & - \\
\hline $\mathrm{CCC}$ & $.0038 * *(.0003)$ & $-.008 * *(.000)$ & $-.008 *(.001)$ & $-.0003 *(.0001)$ \\
\hline $\mathrm{F}$ & $115.57 * *$ & $59.580 * *$ & $2.209^{*}$ & $4.920 * *$ \\
\hline $\mathrm{R}^{2}$ & .574 & .410 & .026 & .054 \\
\hline Adj. $R^{2}$ & .509 & .403 & .014 & .043 \\
\hline \multicolumn{5}{|c|}{$\begin{array}{l}\text { a Standard errors are in parentheses } \\
{ }^{\mathrm{b}} \text { In millions } \\
{ }^{\mathrm{c}} \text { SIC } 52 \text { significant at } .05 \text { level and SIC } 54 \text { significant at } .01 \text { level for Model 2; SIC } 55 \text { significant at } .10 \text { for Model } 4 \\
{ }^{+} p<.10 \\
*^{*} p<.05 \\
*_{*}^{*} p<.01\end{array}$} \\
\hline
\end{tabular}


in cash conversion cycle having a significant impact on the dependent variables in the expected direction (see Tables $4 \mathrm{a}$ and $4 \mathrm{~b}$ ). Although the evidence found in the sample of manufacturing firms was stronger, the results in the retail regression models generally supported the findings in the manufacturing firms.

\begin{tabular}{|c|c|c|c|c|}
\hline Ind. Variables & $\begin{array}{c}\text { Model 1: } \\
\text { Change in CCC }\end{array}$ & $\begin{array}{l}\text { Model 2: } \\
\text { Change in Age of } \\
\text { Inventory }\end{array}$ & $\begin{array}{c}\text { Model 3: } \\
\text { Change in Collection } \\
\text { Period }\end{array}$ & $\begin{array}{c}\text { Model 4: } \\
\text { Change in PDP }\end{array}$ \\
\hline Intercept & $-18.890(22.811)$ & $.641(18.222)$ & $-20.076^{*}(11.509)$ & $.388(15.199)$ \\
\hline Log Sales & $3.021(3.472)$ & $-.481(2.866)$ & $2.926 *(1.752)$ & $-.394(2.313)$ \\
\hline $\mathrm{SIC}^{\mathrm{b}}$ & - & - & - & - \\
\hline Asset Turnover & $1.996^{+}(1.282)$ & $2.522 * *(1.056)$ & $.787(.661)$ & $.991(.875)$ \\
\hline ROIC & $.166^{*}(.084)$ & $.179 * *(.069)$ & $-.031(.043)$ & $-.029(.057)$ \\
\hline NBP & $.0004 * *(.000)$ & $-.00001(.000)$ & $.00001 * *(.000)$ & $-.000006(.000)$ \\
\hline F & $1.708^{*}$ & 1.066 & 1.029 & .718 \\
\hline $\mathrm{R}^{2}$ & .048 & .030 & .027 & .019 \\
\hline Adj. $R^{2}$ & .020 & .002 & .001 & -.008 \\
\hline \multicolumn{5}{|c|}{$\begin{array}{l}{ }^{\mathrm{a}} \text { Standard errors are in parentheses } \\
{ }^{\mathrm{b}} \text { SIC } 23,27 \text { and } 33 \text { significant at } .05 \text { level for Model 1; SIC } 20 \text { and } 25 \text { significant at } .05 \text { level for Model 2; SIC } 36 \text { significant } \\
\text { at } .05 \text { level for Model } 3 \\
{ }^{+} p<.10 \\
*^{*} p<.05 \\
*_{*} p<.01\end{array}$} \\
\hline
\end{tabular}

Table 3b. Stepwise Regression Results for Hypotheses 4a and $4 b^{a}$ (Retail Firms)

\begin{tabular}{|c|c|c|c|c|}
\hline Ind. Variables & $\begin{array}{c}\text { Model 1: } \\
\text { Change in CCC }\end{array}$ & $\begin{array}{c}\text { Model 2: } \\
\text { Change in Age of } \\
\text { Inventory }\end{array}$ & $\begin{array}{c}\text { Model 3: } \\
\text { Change in Collection } \\
\text { Period }\end{array}$ & $\begin{array}{c}\text { Model 4: } \\
\text { Change in PDP }\end{array}$ \\
\hline Intercept & $-54.405^{*}(22.426)$ & $-3.342(17.639)$ & $-24.062 * *(7.148)$ & $-22.186^{+}(11.797)$ \\
\hline Log Sales & $3.246^{*}(1.565)$ & $.500(1.229)$ & $1.619 * *(.499)$ & $1.477^{+}(.823)$ \\
\hline $\mathrm{SIC}^{\mathrm{b}}$ & - & - & - & - \\
\hline Asset Turnover & $.541(1.335)$ & $-.468(1.045)$ & $.270(.422)$ & $1.047(.696)$ \\
\hline ROIC & $.313^{+}(.188)$ & $.137(.148)$ & $-.010(.061)$ & $-.166^{+}(.099)$ \\
\hline NBP & $.0002 *(.000)$ & $-.00001(.000)$ & $.00003 *(.000)$ & $.00001(.000)$ \\
\hline $\mathrm{F}$ & $1.685^{+}$ & .298 & 1.752 & 1.319 \\
\hline $\mathrm{R}^{2}$ & .024 & .004 & .024 & .018 \\
\hline Adj. $R^{2}$ & .010 & -.010 & .010 & -.004 \\
\hline \multicolumn{5}{|c|}{ 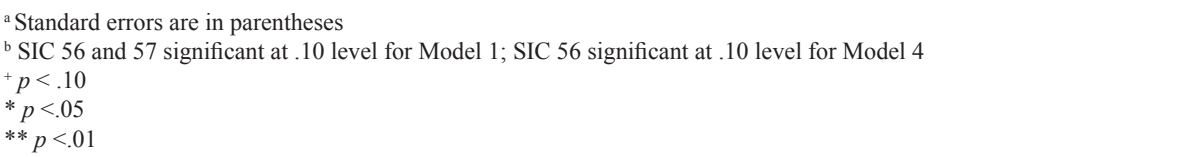 } \\
\hline
\end{tabular}




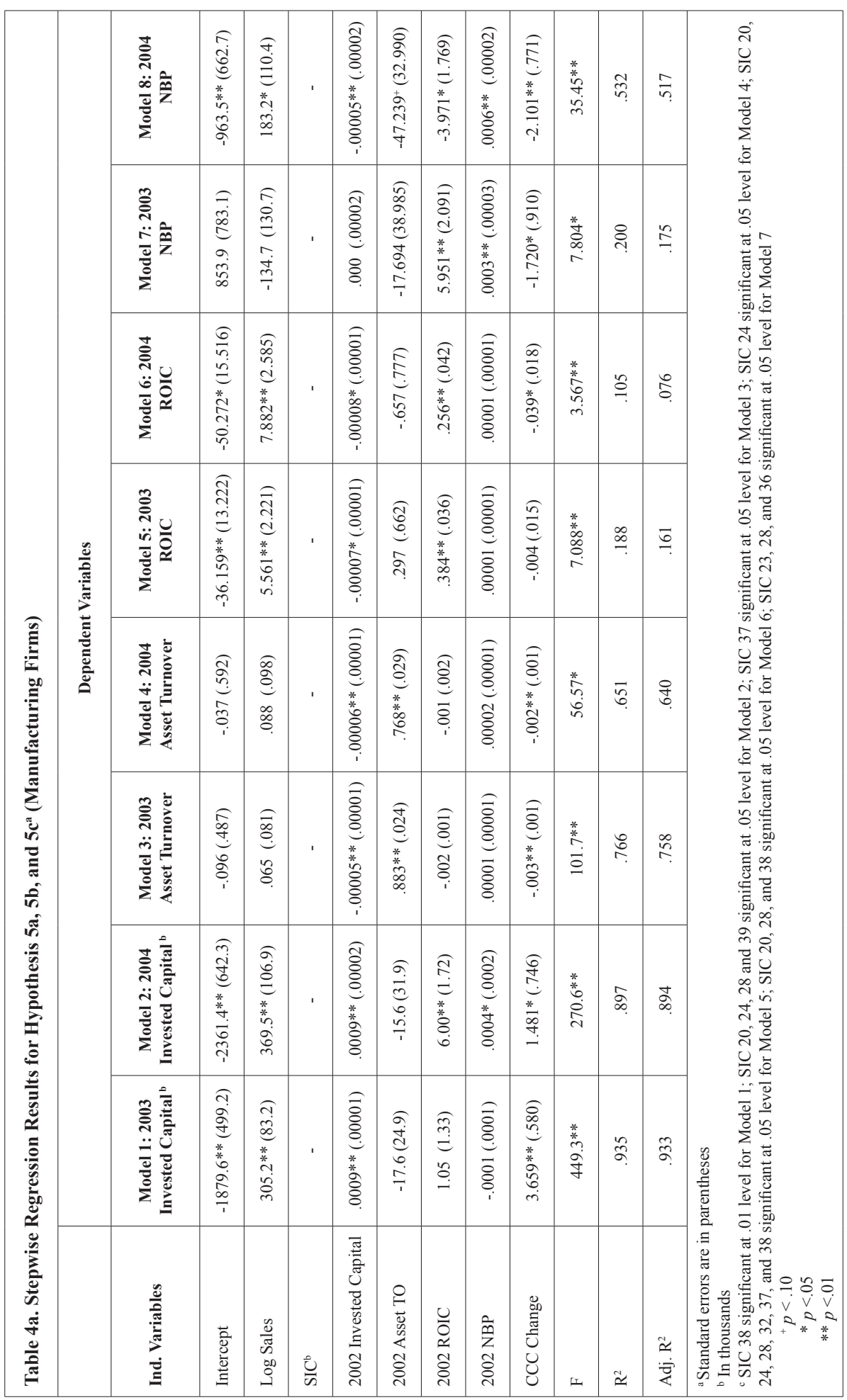




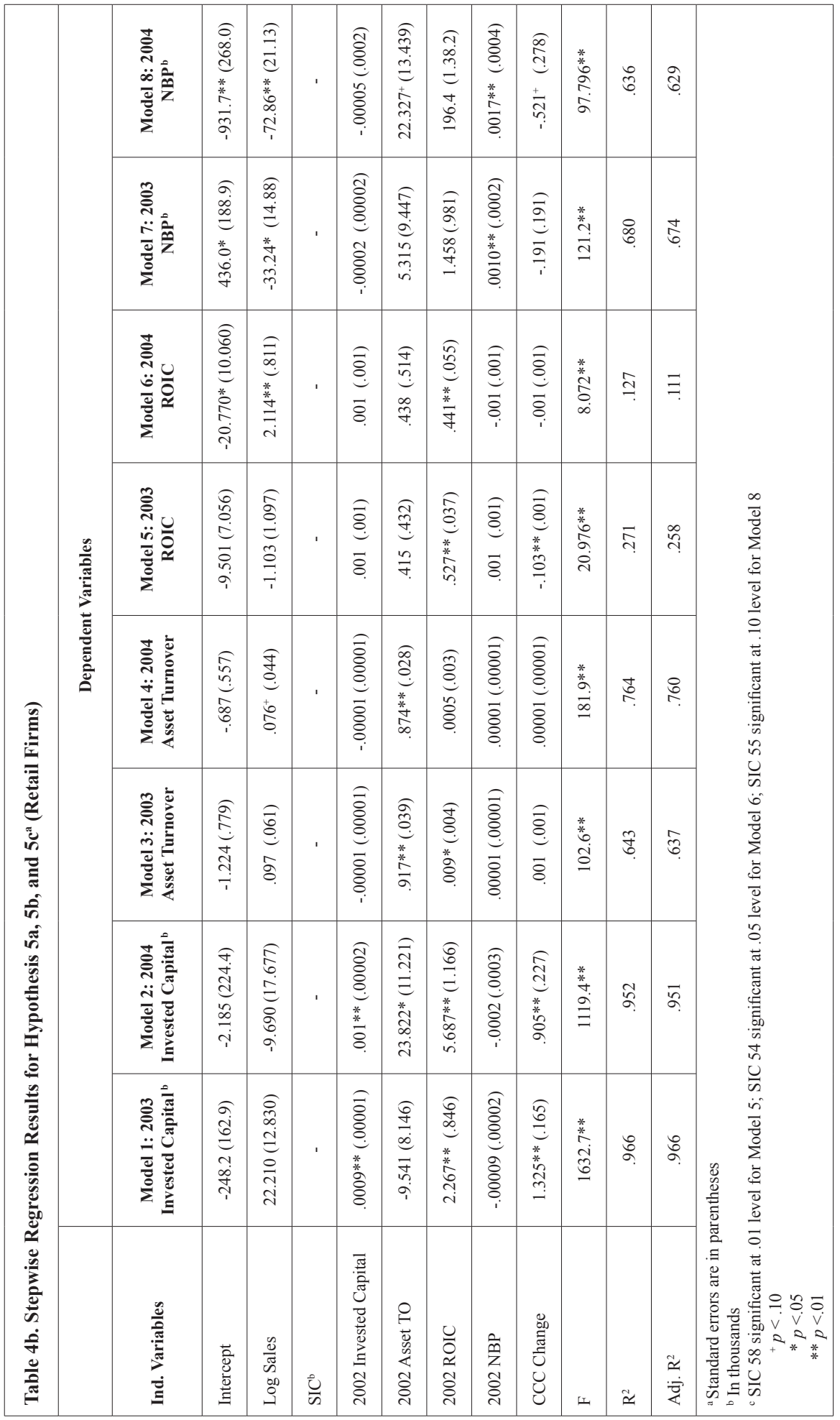




\section{Discussion}

\section{Implications of the Results}

This study attempted to further our understanding of how small firms manage cash flow and whether cash management is related to firm performance. The results of this study provide evidence of three aspects: 1) That the cash conversion cycle is an important concept for small firm owners and managers to understand and monitor; 2) That cash flow management is related to the amount of required invested capital and to firm performance and liquidity, and 3) That small firms tend to be reactive in their approaches to cash flow management. These findings are significant to researchers, educators, and practitioners alike.

The first finding of the study is that firms with shorter cash conversion cycles maintain lower levels of invested capital. This is intuitive from the perspective that firms need to finance receivables and inventory through accruals/payables, interest-bearing debt, and equity. If receivables and inventory are high relative to accruals/payables, more interestbearing debt and equity will be required. While this is consistent with previous assertions (e.g. Soenen, 1993), it is important to demonstrate this relationship empirically given the significance of increased capital needs. Owners of firms with longer cash conversion cycles are forced to search for scarce, expensive debt and equity or to put more of their own capital at risk.

The second finding was also expected: similar to two previous studies of small firms (Garcia-Teurel and Martinez-Solano, 2007; Padachi, 2006), shorter cash conversion cycles had a positive impact on financial performance as measured by asset turnover and return on invested capital. Longer cash conversion cycles result in higher levels of assets and invested capital, which in turn should lead to lower asset turnover and lower return on invested capital. However, it may also be indicative of the overall management of the firm and that inefficient handling of receivables and inventory lead to other inefficiencies in the firm. For instance, there are costs associated with tracking and collecting receivables and with storing and managing inventory; so carrying higher levels of receivables and inventory will result in higher costs of receivables and inventory management. While Shin and Soenen (1998) speculated that this relationship in large firms can be at least partially attributed to the market dominance and bargaining power of high performing firms, it is unlikely that this is true in small firms.

The third finding demonstrated that firms with shorter cash conversion cycles had higher levels of liquidity. This is somewhat counterintuitive and at odds with the widely held notion in corporate finance that there is a tradeoff between liquidity and profitability. These results indicate that by effectively managing cash conversion cycle, a firm can improve returns and liquidity, thereby increasing returns while reducing risk. Again, this is likely driven by the fact that small firms have a limited pool of total capital (Fazarri and Petersen, 1993), and the more that is tied up in receivables and inventory relative to payables, the less that is available for cash liquidity.

Perhaps the most significant outcome of this study are the findings that indicate small firms seem to be reactive in their approach to cash conversion cycle and that changes in cash conversion cycle have a significant impact on the firm. Asset turnover, return on invested capital, and net balance position were all positively related to the change in cash conversion cycle. This means that higher performing firms and firms with more liquidity were more likely to increase their cash conversion cycles, while lower performing firms and firms with lower liquidity were more likely to decrease their cash conversion cycles. 
Further analysis, in fact, revealed that manufacturing firms in the bottom quartile of return on invested capital decreased cash conversion cycle by an average of 2.16 days, while firms in the top quartile increased their cash conversion cycles by an average of 5.42 days; retail firms in the bottom quartile of return on invested capital decreased cash conversion cycle by 6.28 days, while retail firms in the top quartile increased cash conversion cycle by 1.87 days (these mean differences were significant at a .05 level).

Further, decreases in cash conversion cycles were positively related with subsequent firm performance and liquidity. These findings together imply that one action underperforming and illiquid firms take to improve their positions is addressing cash conversion cycle, and that decreasing cash conversion cycle helps to achieve the desired result. Interestingly, the findings indicate that underperforming manufacturing firms did not simply decrease cash conversion cycle by delaying payments to suppliers as one might expect; there was no evidence that performance or liquidity was related to a change in payment deferral period. Rather, it appears that these firms took action to address collection periods and age of inventory instead.

While evidence of reactionary behavior in small firms is not surprising, it does provide the basis for prescriptive advice. Small firm owners and managers often wear many hats and have no shortage of tasks on which to focus. When the firm is performing well and cash is less of an issue, it is easier to pay less attention to collections, to let inventory build up, and to pay bills right away instead of waiting until they are due. When performance suffers and cash is tight, collections, inventory, and payables get more attention and efficiencies improve. The cash conversion cycle is an effective framework for small firm owners and managers to understand cash management and the impact each additional day of inventory, collections, and payment deferral has on cash. It also provides a tool for setting targets and monitoring working capital management on a regular basis.

Of course, there are other considerations in the management of cash conversion cycle worth discussing. For instance, firms are constrained in how much they can reduce cash conversion cycle by the payment terms customers are willing to agree to, by the minimum appropriate level of inventory to maintain to deal with fluctuations in supply and demand, and by payment terms of their suppliers. Another consideration is discounts on inventory for bulk purchases or for quick payments: taking advantage of these discounts is often beneficial to profit margin, but will result in higher inventory levels and/or shorter payment deferral periods. Small firms can use the cash conversion cycle framework to assist in making policy decisions related to the above issues.

\section{Limitations and Future Research}

Due to the nature of the data set, generalizations based on the results of this study should be made with caution. For comparison sake, only manufacturing and retail firms were included in the study, so the results may not be generalizable to other types of small firms. There also may be some self-selection bias among firms that are part of the Kauffman database; these firms may not be entirely representative of all small manufacturing/retail firms. Additionally, because secondary data was used, the study was limited in terms of available control variables. While there is not an apparent reason to believe limitations in the data set are fatal to the study, future studies should address these limitations by using alternative data sets and investigating cash management in non-manufacturing and non-retail firms.

Another limitation of the study has to do with time intervals around measurement of change in cash conversion cycle and its subsequent impact. Only year-end data were available, so it was not apparent when changes in cash conversion cycle took place during the 
year or how quickly these changes had an impact. Using secondary numerical data also does not reveal any intricacies around this process. Future research could take a detailed qualitative approach to shed more light on how this process takes shape; what exactly causes small firm owners to better manage cash conversion cycle (or to become complacent about it), and whether this is part of greater management initiatives (or greater complacency). This would aid in understanding how small firm owners manage, which would be beneficial in developing prescriptions for educators and practitioners.

Future research should also consider what role growth goals and economic conditions play in the relationships between cash conversion cycle and firm performance. It is possible that in some firms this negative relationship can be attributed to growth goals, as firms may invest in working capital (and increase cash conversion cycle) while taking short-term drops in performance to prepare for growth and/or during growth cycles. Likewise, times of economic expansion may incent firms to increase working capital, as they are more confident in their ability to sell inventory and collect on receivables, and this may influence the cash conversion cycle/firm performance relationship.

\section{Conclusion}

This paper outlines a study that analyzed relationships between cash conversion cycle and invested capital, liquidity, and performance of small firms over a three-year period using a financial data set of small U.S. manufacturing and retail firms. Despite its limitations, this study provides a significant contribution to the literature on small business management and entrepreneurship. The data revealed that cash conversion cycle is a significant factor in small firm capital needs, liquidity, and performance, as well as trends that indicate small firm owners may not be proactively managing cash conversion cycle. These findings are significant for small firms and provide a basis for future research on cash flow management in small firms and for educating students and small firm owners on cash flow management.

\section{Contact}

For further information on this article, contact:

Jay J. Ebben. Associate Professor, Schulze School of Entrepreneurship, University of St. Thomas, 2115 Summit Ave., SCH 435, St. Paul, MN 55105

Tel: (651) 962-4118

Fax: (651) 962-5093

E-mail: jjebben@stthomas.edu

Alec C. Johnson, Associate Professor, Schulze School of Entrepreneurship, University of St. Thomas, 2115 Summit Ave., SCH 435, St. Paul, MN 55105

Tel: (651) $962-4121$

Fax: (651) 962-5093

E-mail: acjohnson2@stthomas.edu

\section{References}

Berger, A., and G. Udell. 1995. "Relationship Lending and Lines of Credit in Small Firm Finance." Journal of Business 68(3): 351-381.

Berryman, J. 1983. "Small Business Failure and Bankruptcy: A Survey of the Literature." European Small Business Journal 1(4): 47-59.

Bhide, A. 1992. "Bootstrap Finance: The Art of Start-Ups.” Harvard Business Review 70(6): 109-117. 
Brophy, D., and J. Shulman. 1992. “A Finance Perspective on Entrepreneurship Research.” Entrepreneurship Theory and Practice 16(3): 61-71.

Busenitz L., and J. Barney. 1997. Journal of Business Venturing 12: 9-30.

Carpenter, R., and B. Petersen. 2002. "Is the Growth of Small Firms Constrained by Internal Finance?" Review of Economic Statistics 84(2): 298-309.

Cassar, G. 2004. "The Financing of Business Start-Ups.” Journal of Business Venturing 19(2): 261-283.

Chandler, G., and S. Hanks. 1994. "Market Attractiveness, Resource-Based Capabilities, Venture Strategies, and Venture Performance." Journal of Business Venturing 9(4): 331-350.

Cooper, A., F.J. Gimeno-Gascon, and C. Woo. 1994. "Initial Human and Financial Capital as Predictors of New Venture Performance." Journal of Business Venturing 9(5): 371-395.

Daily, C., and D. Dalton. 1993. "Board of Directors Leadership and Structure: Control and Performance Implications." Entrepreneurship Theory and Practice 17(3): 65-81.

d'Ambroise, G., and M. Muldowney. 1988. "Management Theory for Small Business: Attempts and Requirements." Academy of Management Review 13(2): 226-240.

Deloof, M. 2003. "Does Working Capital Management Affect Profitability of Belgian Firms?" Journal of Business Finance and Accounting 30(3/4): 573-587.

Dodge, H., S. Fullerton, and J. Robbins. 1994. "Stage of the Organizational Life Cycle and Competition as Mediators of Problem Perception for Small Businesses." Strategic Management Journal 15(2): 121-134.

Dunn, P., and L. Cheatham. 1993. "Fundamentals of Small Business Financial Management for Start-Up, Survival, Growth, and Changing Economic Circumstances." Managerial Finance 19(8): 1-13.

Ebben, J., and A. Johnson. 2006. "Bootstrapping in Small Firms: An Empirical Analysis of Change Over Time." Journal of Business Venturing 21(6): 851-865.

Egeln, J., G. Licht, and F. Steil. 1997. "Firm Foundations and the Role of Financial Constraints." Small Business Economics 9(2): 137-150.

Eljelly, A. 2004. "Liquidity-Profitability Tradeoff: An Empirical Investigation in an Emerging Market." International Journal of Commerce and Management 14(2): 48-61.

Fazarri, S., and B. Petersen. 1993. "Working Capital and Fixed Investment: New Evidence on Financing Constraints." RAND Journal of Economics 24(3): 328-342.

Filley, A., and R. Aldag. 1978. "Characteristics and Measurement of an Organizational Typology." Academy of Management Journal 21(4): 578-591.

Forbes, D., and F. Milliken. 1999. "Cognition and Corporate Governance: Understanding Boards of Directors as Strategic Decision-Making Groups.” Academy of Management Review 24(3): 489-505.

Fraser, J. 1998. "The Art of Cash Management," Inc. 20(1): 124-125.

Garcia-Teurel, P., and P. Martinez-Solano. 2007. "Effects of Working Capital Management on SME Profitability." International Journal of Managerial Finance 3(2): 164-177.

George, G. 2005. "Slack Resources and the Performance of Privately-Held Firms." Academy of Management Journal 48(4): 661-676.

Holtz-Eakin, D., D. Joulfaian, and H. Rosen. 1994. "Entrepreneurial Decisions and Liquidity Constraints." RAND Journal of Economics 25(2): 334-347.

Howorth, C., and P. Westhead. 2003. "The Focus of Working Capital Management in UK Small Firms." Management Accounting Research 14(2): 94-111.

Johnson, A., R. Pricer, and B. Nenide. 2004. "Firms Ability to Use Debt." Journal of Applied Business and Economics 6: 1-12.

Jose, M., C. Lancaster, and J. Stevens. 1996. “Corporate Returns and Cash Conversion Cycles.” Journal of Economics and Finance 20(1): 33-47.

Kennedy, D., J. Lakonishok, and W. Shaw. 1992. "Accommodating Outliers and Nonlinearity in Decision Models: Professional Adaptation." Journal of Accounting, Auditing and Finance 7(2): 161-194.

Lazaridis, I., and D. Tryfonidis. 2006. "Relationship Between Working Capital Management and Profitability of Listed Companies in the Athens Stock Exchange." Journal of Financial Management and Analysis 19(1): 26-35.

Levenson, A., and K. Willard. 2000. "Do Firms Get the Financing They Want? Measuring Credit Rationing Experienced by Small Businesses in the U.S." Small Business Economics 14(2): 83-94.

Myers, S. 1984. "The Capital Structure Puzzle." Journal of Finance 39(3): 575-592.

Norton, E. 1991. "Capital Structure and Small Public Firms.” Journal of Business Venturing 6(4): 287-303.

Opiela, N. 2006. "Keeping Small Business Cash Flow on Track.” Journal of Financial Planning 19(7): 26-32.

Padachi, K. 2006. "Trends in Working Capital Management and its Impact on Firms' Performance: An Analysis of Mauritian Small Manufacturing Firms.” International Review of Business Research Papers 2(2): 45-58.

Pissarides, F. 1999. "Is Lack of Funds the Main Obstacle to Growth? EBRD’s Experience With Small- and Medium-Sized Businesses in Central and Eastern Europe." Journal of Business Venturing 149(5/6): 519-539. 
Rajan, R., and L. Zingales. 1995. "What Do We Know About Capital Structure? Some Evidence From International Data." Journal of Finance 50(5): 1421-1460.

Richards, V., and E. Laughlin. 1980. “A Cash Conversion Cycle Approach to Liquidity Analysis.” Financial Management 9(1): 32-38.

Shane, S., and D. Cable. 2002. "Network Ties, Reputation, and the Financing of New Ventures." Management Science 48(3): 364-381.

Shin, H., and L. Soenen. 1998. "Efficiency of Working Capital Management and Corporate Profitability." Financial Practice and Education 8(2): 37-45.

Smith, K. 1973. "State of the Art of Working Capital Management." Financial Management (Autumn): 50-55.

Soenen, L. 1993. "Cash Conversion Cycle and Corporate Profitability." Journal of Cash Management 13(4): 53-57.

Stiglitz, J., and A. Weiss. 1981. "Credit Rationing in Markets With Imperfect Information." American Economic Review 73(3): 246-249.

Stinchcombe, A. 1965. “Organizations and Social Structure.” In J.G. March (ed.), Handbook of Organizations. Rand-McNally, Chicago, IL.

Storey, D. 1994. "The Role of Legal Status in Influencing Bank Financing and New Firm Growth." Applied Economics 26(2): 129-136.

Timmons, J.A. 1999. New Venture Creation: Entrepreneurship for the $21^{\text {st }}$ Century (5 ${ }^{\text {th }}$ ed.). McGraw Hill: New York, NY.

Wang, Y. 2002. "Liquidity Management, Operating Performance, and Corporate Value: Evidence from Japan and Taiwan.” Journal of Multinational Financial Management 12(2): 159-169.

Watson, R., and N. Wilson. 2002. "Small and Medium Size Enterprise Financing: A Note on Some of the Empirical Implications of a Pecking Order.” Journal of Business Finance and Accounting 29(3/4): 557-578.

Winborg, J., and H. Landstrom. 2001. "Financial Bootstrapping in Small Businesses: Examining Small Business Managers' Resource Acquisition Behaviors.” Journal of Business Venturing 16(3): 235-254. 


\section{Contributors}

LEO PAUL DANA holds degrees from McGill University and from the École des Hautes Études Commerciales (Montréal). He has been tenured at the University of Canterbury since 1999. He is on leave and currently at GSCM-Montpellier Business School, France (Groupe Sup de Co Montpellier). He formerly served as Visiting Professor of Entrepreneurship at INSEAD and Deputy Director of the International Business MBA Programme at Nanyang Business School, in Singapore.

JAY EBBEN is an Associate Professor of Entrepreneurship at the University of St. Thomas in St. Paul, Minnesota. His teaching and research mainly focuses on small business strategy and small business finance.

ALEC JOHnSON is an Associate Professor of Entrepreneurship at the University of St. Thomas in St. Paul, Minnesota. His teaching and research mainly focuses on new venture development and small business management.

ASHIM KUMAR KAR is a project researchers at the Hanken School of Economics in Helsinki, Finland, with current research interests in the areas of microfinance, poverty and development economics.

ABDULRAHIM K. KOWATLY is a Lebanese business executive operating in the Arab Gulf.

FRANK LASCH is associate professor at GSCM-Montpellier Business School, France (Groupe Sup de Co Montpellier). He completed his bi-national $\mathrm{PhD}$ in Economic Geography (2002: University of Regensburg, Germany \& University of Montpellier III, France) and received his certificate for the supervision of doctoral research (Habilitation) in Management Science (University of Montpellier I) in 2007. His research interests are the relationship between entrepreneurship and the regional environment, the influence of government policy on SMEs, start-up survival and growth, and entrepreneurship in the ICT sector. He is currently research director of GSCM (GSCM research centre website: www. cerom.org/).Contact: f.lasch@supco-montpellier.fr.

PHILIP W. ZGHEIB is a senior Fulbright scholar, and Assistant Professor of Management and entrepreneurship in the Olayan School of Business at the American University of Beirut. His research interests include entrepreneurship, business ethics, gender issues, business communications, and knowledge management. 